\title{
Krim ekstrak etanol biji mengkudu (Morinda citrifolia) sama efektifnya dengan krim hidrokuinon dalam mencegah peningkatan jumlah melanin kulit marmut (Cavia porcellus) yang dipapar sinar ultraviolet $B$
}

\author{
${ }^{1}$ Rahmi Sofiana \\ ${ }^{2}$ Anak A. G. P. Wiraguna \\ ${ }^{3}$ Wimpie Pangkahila
}

\author{
${ }^{1}$ Program Pascasarjana Anti-Aging Medicine \\ ${ }^{2}$ Departemen Penyakit Kulit dan kelamin, \\ ${ }^{3}$ Departemen Andrologi dan Seksologi \\ Fakultas Kedokteran Universitas Udayana Denpasar \\ Email: drrahmisofiana@yahoo.com
}

\begin{abstract}
Ultraviolet B (UVB) ray may cause skin hyperpigmentation due to increased melanin level. Noni seeds (Morinda citrifolia) extract was a strong candidate as an antioxidant and whitening agent. This study was aimed to prove the effect of noni seeds extract cream in prevention the increase of melanin in UVB-exposed guinea pig (Cavia porcellus). This was a true experimental study using posttest only control group design. Subjects were 30 guinea pigs divided into 3 groups, each of 10 guinea pigs. Group 1, the control group, was treated with UVB exposure and basic cream; group 2 was treated with UVB and 4\% noni seed cream; and group 3 was treated with UVB and 4\% hydroquinone cream. A total of $390 \mathrm{~mJ} / \mathrm{cm}^{2}$ ultraviolet B dosage was given for 2 weeks. Histopathological examination with Masson-Fontana staining was performed to evaluate the melanin areas with black color. The amount of melanin was calculated by the percentage of pixel areas of melanin and was compared with the pixels of all epidermal tissues. The results showed that the highest number of melanin was in group $1(10.61 \pm 5.33 \%)$, while in group 2 was $1.4 \pm 0.65 \%$, and in group 3 was $0.45 \pm 0.23 \%$. There was a significant difference between the control group and group 2 as well as group $3(P<0.05)$ whereas no significant difference was found between group 2 and group $3(P>0.05)$. Conclusion: The $4 \%$ noni seeds extract (Morinda citrifolia) cream could prevent the increase of skin melanin in UVB-exposed guinea pig as effective as $4 \%$ hydroquinone cream.
\end{abstract}

Keywords: noni seeds extract cream, melanin, ultraviolet B, guinea pigs

\footnotetext{
Abstrak: Paparan sinar ultraviolet B (UVB) mengakibatkan terjadinya kelainan hiperpigmentasi yang ditandai dengan peningkatan jumlah melanin. Ekstrak biji mengkudu memiliki kombinasi zat aktif yang dapat bekerja sinergis dalam mencegah peningkatan jumlah melanin. Penelitian ini bertujuan untuk membuktikan efek pemberian krim ekstrak biji mengkudu (Morinda citrifolia) dalam mencegah peningkatan jumlah melanin kulit marmut (Cavia porcellus) yang dipapar sinar UVB. Jenis penelitian ialah eksperimental dengan randomized posttest only control group design menggunakan 30 ekor marmut jantan yang dibagi atas 3 kelompok, masing-masing 10 ekor. Kelompok 1 yaitu kelompok kontrol, diberi paparan sinar UVB dan diolesi krim dasar. Kelompok 2 diberi paparan sinar UVB dan krim ekstrak biji mengkudu 4\%. Kelompok 3 diberi paparan sinar UVB dan krim hidrokuinon 4\%. Dosis total UVB yaitu $390 \mathrm{~mJ} / \mathrm{cm}^{2}$ diberikan selama 2 minggu. Pemeriksaan histopatologik jaringan kulit dengan pewarnaan Masson- Fontana. Jumlah melanin dihitung dengan persentase pixel luas area melanin dibandingkan dengan pixel
} 
seluruh jaringan epidermis. Hasil penelitian menunjukkan jumlah melanin pada Kelompok 1 sebesar 10,61 $\pm 5,33 \%$; pada kelompok 2 sebesar $1.4 \pm 0.65 \%$, dan pada kelompok 3 sebesar $0,45 \pm 0,23 \%$. Terdapat perbedaan bermakna antara kelompok 1 dengan kelompok 2 dan 3 ( $P$ $<0,05)$. Perbandingan antara kelompok 2 dan 3 tidak berbeda bermakna dalam mencegah peningkatan jumlah melanin $(P>0,05)$. Simpulan: Krim ekstrak biji mengkudu 4\% dapat mencegah peningkatan jumlah melanin kulit marmut yang dipapar sinar UVB, dan memiliki efektifitas yang sama dengan krim hidrokuinon $4 \%$.

Kata kunci: krim ekstrak biji mengkudu, melanin, ultraviolet B, marmut

Penuaan ialah proses alami yang terjadi pada semua mahluk hidup yang dimulai dari semenjak lahir di dunia. Proses penuaan ini dihubungkan dengan menurunnya fungsi tubuh sehingga terjadi penurunan kualitas hidup saat seseorang mencapai usia lanjut. Proses penuaan disebabkan oleh faktor intrinsik seperti genetik, dan hormonal; dan faktor ekstrinsik seperti sinar matahari (ultraviolet), kelembaban udara, dan asap rokok. ${ }^{1}$

Paparan sinar UV akan menstimulasi aktivitas enzim tirosinase dan meningkatkan jumlah melanosit yang memroduksi melanin. Akibatnya transfer melanosome dari melanosit ke keratinosit akan meningkat, demikian pula melanin akan meningkat. ${ }^{2}$ Pembentukan melanin yang berlebihan dan akumulasi jumlah melanin yang abnormal di beberapa bagian kulit akibat paparan radiasi ultraviolet berlebihan akan menyebabkan bercak hiperpigmentasi yang dianggap sebagai masalah estetika. ${ }^{3}$

Saat ini di pasaran banyak produk yang dikenal sebagai krim pencerah. Bahan topikal yang digunakan untuk anti hiperpigmentasi biasanya mengandung zat yang menghambat melanogenesis. Hidrokuinon $4 \%$ merupakan baku emas terapi hiperpigmentasi selama bertahun-tahun. Mekanisme kerjanya ialah menghambat kerja enzim tirosinase, merusak sel melanosit langsung, mempercepat degradasi melanosom, dan menghambat sintesis enzim melanogenesis. ${ }^{4}$ Penggunaan hidokuinon jangka panjang dapat menimbulkan efek samping yaitu: iritasi, rebound phenomenon, dan okronosis. ${ }^{5}$ Oleh karena itu penggunaan hidrokuinon saat ini sudah mulai sangat dibatasi. Berdasarkan hal tersebut, maka perlu dicari bahan-bahan pemutih kulit lain yang bersifat alami dengan efek samping yang lebih sedikit.

Buah mengkudu (Morinda citifolia) merupakan tanaman asli yang berasal dari Asia Tenggara dan banyak ditemukan di Indonesia. Buah mengkudu merupakan salah satu tanaman yang mudah didapatkan dan secara empiris telah digunakan di masyarakat tertentu di Indonesia sebagai obat tradisional. Dari hasil pemeriksaan fitokimia ekstrak biji mengkudu diketahui mengandung antioksidan, flavonoid, fenol, tannin dan vitamin C. Pada pemeriksaan biji mengkudu di Pusat Studi Obat Bahan Alam Fakultas Farmasi Universitas Indonesia didapatkan aktivitas antioksidan ekstrak dengan metode DPPH (IC50) sebesar 48,924 ug/ml; kadar total flavonoid ekstrak 34,6\% kuersetin; dan kadar vitamin C ekstrak 13,99\%. Tingkat kekuatan antioksidan biji mengkudu dengan metode DPPH sebesar 48,924 ug/ml menurut nilai IC50 tergolong sangat kuat. ${ }^{6}$

Senyawa polifenol (flavonoid) yang merupakan kelompok terbesar berefek menghambat proses melanogenesis sebagai tirosinase inhibitor. ${ }^{7}$ Vitamin $\mathrm{C}$ merupakan antioksidan poten yang mencegah sintesis melanin dengan cara menghambat inflamasi serta autooksidasi DOPA dan Dopaquinon. ${ }^{8}$ Suatu penelitian in vitro telah dilakukan untuk menguji aktivitas penghambatan melanogenesis mengkudu terhadap kulit. Uji aktivitas tirosinase inhibitor dan aktivitas antioksidan dengan metode DPPH yang dilakukan terhadap ekstrak mengkudu mendapatkan ekstrak biji mengkudu 500ug/ml mempunyai potensi tirosinase inhibitor dan antioksidan tertinggi dibanding buah dan daun mengkudu. ${ }^{9}$ Penelitian in vitro yang 
melibatkan penggunaan B16 murine melanoma cells sebagai tes model melanogenesis mendapatkan konsentrasi 12,5 sampai $200 \mathrm{ug} / \mathrm{ml}$ dari ekstrak biji mengkudu menghambat produksi melanin. ${ }^{9}$

Penelitian pendahuluan dilakukan pada kulit marmut yang dipapar sinar UVB dan dioles krim ekstrak biji mengkudu dengan konsentrasi 1\%, 2\%, dan 4\%. Dari hasil kulit yang dioles krim ekstrak biji mengkudu $4 \%$ didapatkan jumlah melanin paling sedikit. Berdasarkan hasil penelitian pendahuluan maka konsentrasi yang digunakan untuk penelitian ini ialah $4 \%$. Untuk mengetahui efek ekstrak biji mengkudu dalam mencegah peningkatan jumlah melanin pada kulit akibat paparan sinar UVB, maka dilakukan penelitian in vivo pada kulit marmut (Cavia porcellus) dan untuk mengetahui efektivitasnya maka dibandingkan dengan hidrokuinon $4 \%$.

\section{METODE PENELITIAN}

Jenis penelitian ini ialah eksperimental dengan menggunakan randomized post test only control group design. ${ }^{10}$ Subjek penelitian ini ialah 30 ekor marmut (Cavia Porcellus) strain lokal, jenis kelamin jantan, berusia 3 bulan, berat badan kurang lebih 300-350 gram, dan sehat. Pada kelompok subjek penelitian dilakukan alokasi sampel secara random sehingga didapatkan 3 kelompok (P0, P1, dan P2), masing-masing berjumlah 10 ekor marmut. Kelompok P0 sebagai kelompok kontrol, diberikan perlakuan dengan paparan sinar UVB dan pemberian krim dasar. Kelompok P1 sebagai kelompok perlakuan 1, diberikan paparan sinar UVB dan pemberian krim ekstrak biji mengkudu $4 \%$. Kelompok P2 yaitu kelompok perlakuan 2, diberikan paparan sinar UVB dan pemberian krim hidrokuinon $4 \%$.

Persiapan penelitian meliputi adaptasi tikus dalam kondisi laboratorium selama 7 hari. Perlakuan dalam penelitian ini berlangsung selama 2 minggu berupa paparan sinar UVB sebanyak 3 kali seminggu (hari Senin, Rabu dan Jum'at. Pada setiap paparan diberikan dosis sinar UVB $65 \mathrm{~mJ} / \mathrm{cm}^{2}$ selama 65 detik. Pada hari pemaparan UVB, krim pada setiap kelompok dioles 20 menit sebelum dan 4 jam sesudah paparan sinar UVB. Pada hari tanpa pemaparan UVB, krim tetap dioles 2 kali sehari. Pada 48 jam setelah paparan, marmut dieutanasia menggunakan ketamin dosis berlebih (100 mg/kgbb) secara intraperitoneal. Daerah punggung yang akan diambil kulitnya, dibersihkan dari bulu kemudian dibuat preparat histopatologik menggunakan pewarnaan MassonFontana yang memberikan warna hitam pada melanin. Penghitungan jumlah melanin dilakukan dengan persentase pixel luas area melanin dibandingkan dengan pixel seluruh jaringan epidermis.

\section{HASIL PENELITIAN DAN BAHASAN}

Hasil penelitian menunjukkan rerata jumlah melanin pada kelompok P0 yang diberikan krim dasar ialah 10,61 $\pm 5,33 \%$, rerata jumlah melanin pada kelompok P1 yang diberikan krim eksrak mengkudu $4 \%$ ialah $1,40 \pm 0,65 \%$, dan pada kelompok P2 yang diberi krim hidrokuinon ialah $0,45 \pm 0,23 \%$. Analisis kemaknaan dengan Anova (Tabel 1) menunjukkan bahwa nilai $F=32,779$ dan nilai $P=0,000$. Hal ini berarti ketiga kelompok memiliki rerata jumlah melanin yang berbeda sangat bermakna $(P<0,001)$.

Tabel 1. Rerata jumlah melanin antar kelompok

\begin{tabular}{llccc}
\hline \multicolumn{1}{c}{ Kelompok } & N & $\begin{array}{c}\text { Rerata jumlah } \\
\text { melanin }(\%)\end{array}$ & F & $\boldsymbol{P}$ \\
\hline Kelompok P0 (Krim Dasar) & 10 & $10,61 \pm 5,33^{\mathrm{a}}$ \\
Kelompok P1 (Biji Mengkudu) & 10 & $1,40 \pm 0,65^{\mathrm{b}}$ & 32,779 & 0,000 \\
Kelompok P2 (Hidrokuinon) & 10 & $0,45 \pm 0,23^{\mathrm{b}}$ & & \\
*Notasi (a, b) yang berbeda menunjukkan berbeda bermakna $(P<0,05)$ & &
\end{tabular}




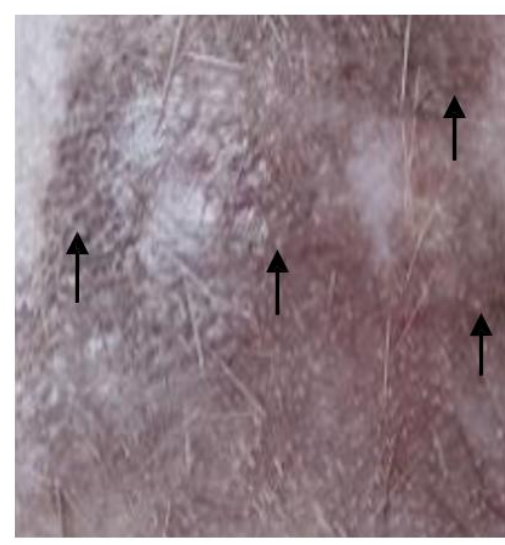

Kelompok 1

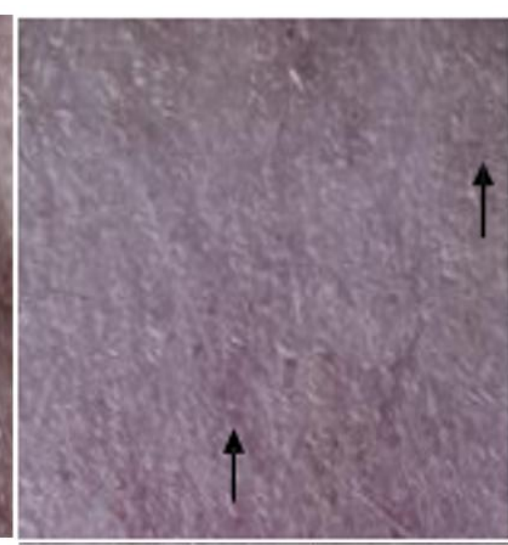

Kelompok 2

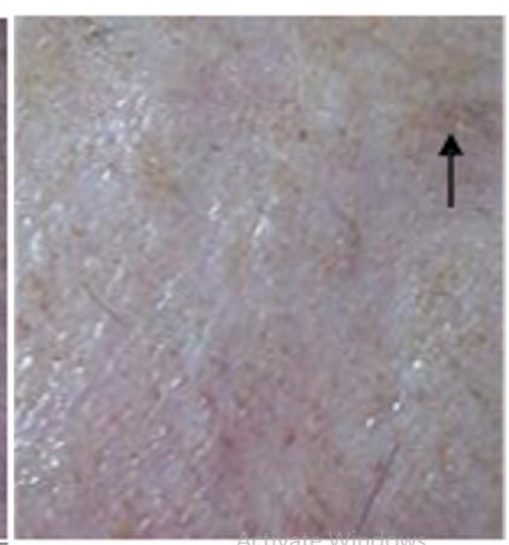

Kelompok 3

Gambar 1. Gambaran klinis kulit marmut setelah perlakuan. Gambaran hiperpigmentasi pada kulit marmut ditunjuk oleh tanda panah. Pada kelompok 1 (kontrol) terlihat lesi hiperpigmentasi yang luas; pada kelompok 2 (krim ekstrak biji mengkudu 4\%) terlihat lesi hiperpigmentasi yang lebih sedikit dibanding kelompok kontrol; pada kelompok 3 (krim hidrokuinon 4\%) terlihat lesi hiperpigmentasi yang paling sedikit.
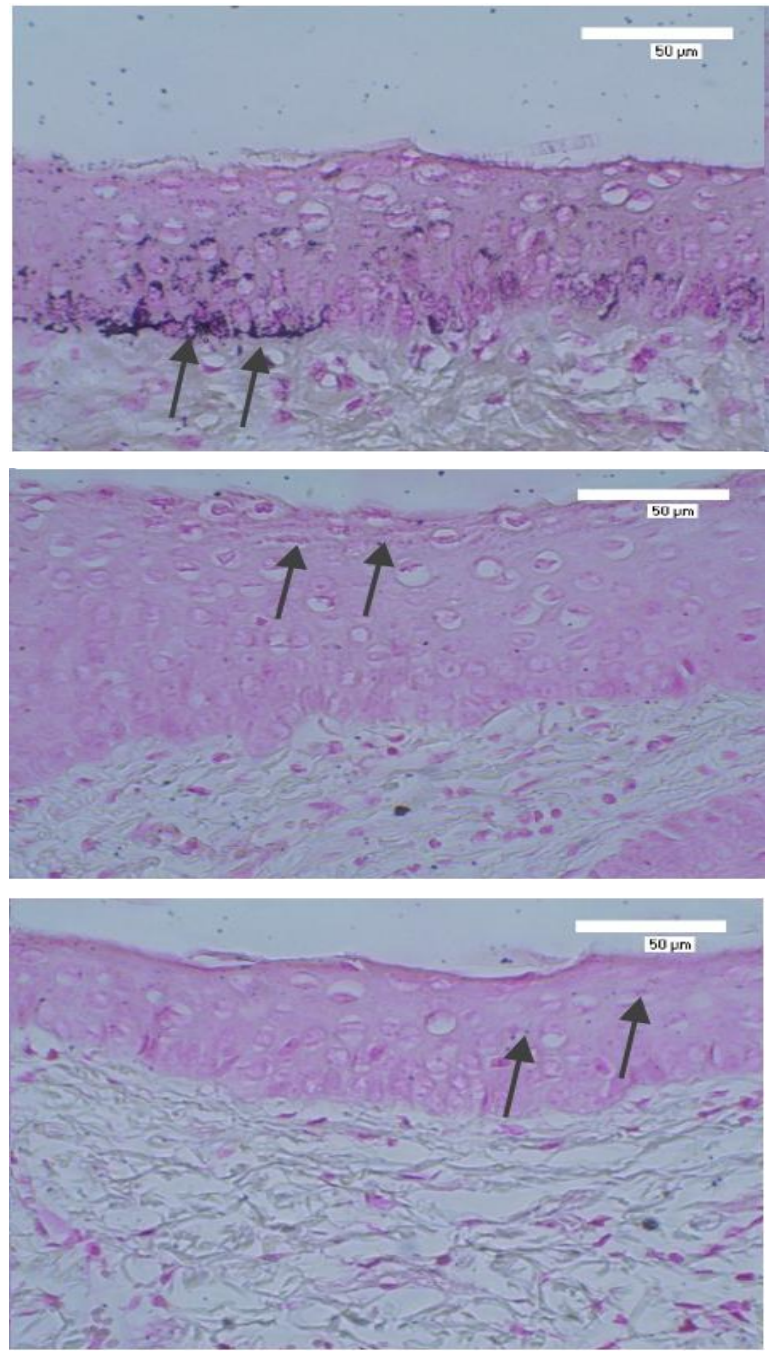

Kelompok 1 (kontrol). Terlihat kumpulan melanin berwarna hitam yang padat berkelompok banyak pada area basal epidermis dan lapisan atas epidermis
Kelompok 2 (krim ekstrak biji mengkudu 4\%). Terlihat melanin berwarna hitam, sedikit berkelompok, dan sedikit menyebar ke lapisan atas epidermis.

Gambar 2. Gambaran melanin kulit marmut dengan pewarnaan Masson-Fontana

Kelompok 3 (krim hidrokuinon 4\%). Terlihat melanin berwarna hitam yang tidak berkelompok dan tidak padat di basal epidermis dan sedikit menyebar ke lapisan atas epidermis. 
Uji lanjutan untuk mengetahui perbedaan individual antar kelompok menggunakan Least Significance Difference (LSD) test menunjukkan bahwa terdapat perbedaan nyata antara kelompok P0 dengan kelompok lainnya $(P<0,01)$, dan tidak terdapat perbedaan antara kelompok P1 dan kelompok P2 $(P>0,05)$.

Radiasi sinar UV ialah sumber radikal bebas yang merupakan salah satu faktor eksternal penyebab penuaan kulit. Respon kulit terhadap radiasi UV dengan dua cara yaitu menebalkan stratum korneum dan filter melanin pada epidermis. Keratin dan protein pada stratum korneum bertindak sebagai pemecah dan pengabsorbsi UV. Melanosit dan keratinosit memiliki respon yang sangat cepat terhadap sinar UV, baik secara parakrin maupun autokrin.

Radiasi sinar UV dapat menyebabkan peningkatan pigmentasi kulit yang disebut tanning melalui beberapa cara antara lain peningkatan kerja enzim melanogenik, peningkatan transfer melanosom menuju keratinosit, peningkatan aktivitas dendritik sel melanosit, dan kerusakan DNA akan menstimulasi proses melanogenesis itu sendiri. ${ }^{11}$ Paparan sinar UV meningkatkan ekspresi beberapa sitokin, hormon dan growth factors yang bekerja sebagai sinyal parakrin yang akan ditangkap oleh reseptor permukaan melanosit sehingga akan mengaktifkan jalur terkait sintesis dan distribusi melanin. ${ }^{12}$

Paparan sinar UVB meningkatkan jumlah melanosit dan peningkatan proses melanogenesis. Seluruh spektrum sinar UV akan bereaksi dengan molekul kromofor yang akan menyerap sinar UV ini yaitu molekul purin, pirimidin, serta asam amino triptofan dan tirosin. Selain itu, proses sintesis melanin secara langsung juga dapat disebabkan oleh nitric oxide (NO). Telah diketahui bahwa NO ialah molekul messenger intra dan intersel, yang akan meningkatkan cyclic guanosine monophosphate (cGMP) sehingga menstimulasi proses sintesis melanin. ${ }^{12}$

Mengkudu merupakan salah satu tanaman yang tumbuh hampir di seluruh wilayah kepulauan Indonesia dan lebih popular digunakan untuk pengobatan dan bahan makanan. ${ }^{13}$ Hasil uji fitokimia ekstrak biji mengkudu diketahui mengandung antioksidan, flavonoid, fenol, tannin, dan vitamin C. Pemeriksaan biji mengkudu pada Pusat Studi Obat Bahan Alam di Fakultas Farmasi Universitas Indonesia mendapatkan aktivitas antioksidan ekstrak dengan metode DPPH (IC50) sebesar 48,924ug/ml dengan kadar total flavonoid ekstrak $34,6 \%$ kuersetin, dan kadar vitamin C ekstrak 13,99\%. Penilaian tingkat kekuatan antioksidan biji mengkudu dengan metode DPPH sebesar $48,924 \mathrm{ug} / \mathrm{ml}$ yang berdasarkan IC50 temasuk golongan antioksidan yang sangat kuat. $^{9}$

Senyawa polifenol (flavonoid) yang merupakan kelompok terbesar berefek menghambat proses melanogenesis sebagai tirosinase inhibitor. Disamping itu, polifenol juga berefek melindungi kulit dari radiasi UV yang dapat mengakibatkan terjadinya kanker kulit. Polifenol memiliki efek anti inflamasi, imunomodulator, memperbaiki DNA yang rusak, dan memperbaiki fungsi sel. ${ }^{14}$ Polifenol merupakan kelompok tirosinase inhibitor terbesar yang dapat menghambat proses melanogenesis dan mencegah meningkatnya jumlah melanin di lapisan epidermis. ${ }^{7}$

Hal tersebut di atas sesuai dengan hasil penelitian ini yang menunjukkan rerata jumlah melanin pada kelompok krim dasar ialah 10,61 $\pm 5,33 \%$, sedangkan rerata jumlah melanin pada kelompok P1 yang diberikan krim eksrak mengkudu $4 \%$ ialah $1,40 \pm 0,65 \%$ ( $P<0,001)$. Hasil penelitian terdahulu juga mendukung hasil penelitian ini. Uji aktivitas tirosinase inhibitor dan aktivitas antioksidan dengan metode DPPH yang dilakukan terhadap ekstrak mengkudu mendapatkan ekstrak biji mengkudu $500 \mu \mathrm{g} / \mathrm{ml}$ mempunyai potensi tirosinase inhibitor dan antioksidan tertinggi dibanding bagian buah dan daun mengkudu. ${ }^{9}$ Demikian pula hasil penelitian in vitro menggunakan $\mathrm{B} 16$ murine melanoma cells sebagai tes model melanogenesis in vitro, melaporkan konsentrasi 12,5-200 $\mu \mathrm{g} / \mathrm{ml}$ dari ekstrak biji 
mengkudu menghambat produksi melanin. ${ }^{9}$

Penghambatan melanin dari hasil penelitian terdahulu ialah karena kandungan utama mengkudu, yaitu 3,3bisdemethylpinoresinol dan Americanin A bekerja melalui aktivasi jalur extracelluler signal regulated kinase (ERK) dengan cara menghambat fosforilasi p38 mitogen activated protein kinase (MAPK) yang akan menghambat aktivitas microphtalmiaassociated transcription factor (MITF) dan akhirnya mengurangi produksi melanin. ${ }^{9,15}$

Hasil penelitian ini juga menunjukkan bahwa tidak terdapat perbedaan antara kelompok yang diberikan krim ekstrak mengkudu 4\% (P1) dengan kelompok yang diberikan krim hidrokuinon 4\% (P2). Hal ini mengindikasikan bahwa efektifitas kedua senyawa ini sama dalam mencegah peningkatan melanin pada kulit yang dipapar sinar UVB. Hidrokuinon ialah bahan pemutih yang sangat sering digunakan pada saat ini, terutama untuk melasma dan kelainan hiperpigmentasi dengan mekanisme kerja menghambat kerja enzim tirosinase, merusak sel melanosit secara langsung, mempercepat degradasi melanosom, dan menghambat sintesis enzim melanogenesis. ${ }^{4,5}$

\section{SIMPULAN}

Berdasarkan hasil penelitian ini, dapat disimpulkan bahwa krim ekstrak biji mengkudu (Morinda citifolia) dapat mencegah peningkatan jumlah melanin kulit mamut (Cavia porcellus) yang dipapar sinar UVB serta memiliki efektivitas yang sama dengan krim hidrokuinon $4 \%$.

\section{DAFTAR PUSTAKA}

1. Pangkahila W. Anti Aging Medicine (1st ed). Jakarta: Kompas, 2007; p. 1-52.

2. Baumann L, Saghari S. Photoaging. In: Baumann L, Saghari S., Weisberg E, editors. Cosmetic Dermatology (2nd ed). New York: McGrawHill, 2009; p. 34-40.

3. Choi M, Shin H. Anti melanogenesis effect of quercetin. Cosmetics. 2016;3(18): 1-16.
4. Bruce S. Safety and efficacy of a novel multimodality hydroquinone-free skin brightener over six months. J Drugs Dermatol. 2013;12(3):S27-31.

5. Baumann, L, Alleman IB. Depigmentation agent. In: Baumann L, Saghari S, Weisberg E, editors. Cosmetic Dermatology (2nd ed). New York: McGraw Hill, 2009; p. 280-8.

6. Armala MM. Daya antioksidan fraksi air ekstrak herba kenikir dan profil KLT [Skripsi]. Yogyakarta: Fakultas Farmasi Universitas Islam Indonesia; 2009.

7. Chang TS. An update review of tyrosinase inhibitors. Int J Mol Sci. 2009;10(6): 2440-75.

8. Smith M, Vicanova J, Pavel S. The hunt for skin whitening agents. Int $\mathbf{J}$ Mol Sci. 2009;10(12):5326-49.

9. Matsuda H, Masuda M, Murata K, Abe Y, Uwaya A. Study of the antiphotoaging effect of noni (Morinda citifolia). In: Guy HT, editor. Melanoma, from Early Detection to Treatment. INTECH: CC BY 3.0 license, 2013; p. 953-978. DOI: $10.5772 / 53621$.

10. Marczyk GR, DeDematteo D, Festinger D. Experimental design. In: Dematteo, D, editor. Essential of Research Design and Methodology (1st ed). New Jersey: John-Wiley. 2005; p. 48-56.

11. Kindred C, Halder RM. Pigmentation and skin of color. In: Draelos, Z.D., editor. Cosmetic Dermatology Products and Procedures (1st ed). New Jersey: Wiley-Blackwell, 2010; p. 27-35.

12. Costin GE, Hearing VJ. Human skin pigmentation: melanocytes modulate skin color in response to stress. FASEB J. 2007;21(4):976-94.

13. Waha MC. Sehat dengan Mengkudu (2nd ed). Jakarta: PT Mitra Sitta Falah (MSF Group), 2001; p. 3-31.

14. Pandey KB, Rizvi SI. Plant polyphenol as dietary antioxidant in human health and disease. Oxid Med Cell Longev. 2009;2(5):270-8.

15. Chang TS. Natural melanogenesis inhibitors acting through the down-regulation of tyrosinase activity. Materials. 2012;5(9):1661-85. 